\title{
37. ISOTOPE CHRONOSTRATIGRAPHY AND CARBONATE RECORD FOR QUATERNARY SITE 619, PIGMY BASIN, LOUISIANA CONTINENTAL SLOPE ${ }^{1}$
}

\author{
Douglas F. Williams, University of South Carolina \\ and \\ Barry Kohl, Chevron U.S.A., Inc. ${ }^{2}$
}

\begin{abstract}
A detailed oxygen-isotope record and planktonic foraminiferal biostratigraphy are used to construct a chronostratigraphic framework for Site 619, Pigmy Basin, on the Louisiana continental slope. Within this framework, sediments accumulated in Pigmy Basin at a fairly constant rate over the last 105,000 yr. The oxygen-isotope record shows evidence for periods of freshwater run-off at times other than glacial terminations. Increased carbonate contents are also associated with these events.
\end{abstract}

\section{INTRODUCTION}

The depositional systems along the northwestern continental slope off Louisiana result from a prograding clastic-hemipelagic wedge of Tertiary and Cretaceous sediments over an underlying thick sequence of evaporitic salt (Gealy, 1955; Murray, 1961; Powell and Woodbury, 1971; Martin and Bouma, 1978). Salt diapirism beneath this wedge has produced a hummocky topographic relief with a large number of intraslope basins. The Pigmy Basin is typical of a blocked-canyon type intraslope basin (Bouma, 1983; Intraslope Basin Introduction and Summary, this volume) and is filled primarily with pelagic and hemipelagic sediments with only minor interruptions by localized mass movement and turbidite deposits (Site 619 chapter, this volume). Site 619 was located in Pigmy Basin to recover a complete sequence of upper Tertiary sediments for paleoenvironmental, sedimentological, and geochemical studies.

In this brief report, we describe the stable oxygenand carbon-isotope records of planktonic foraminifers from the hydraulic piston cored (HPC) section of Site 619. Our objective is to develop a chronostratigraphic record for Site 619 by comparing the $\delta^{18} \mathrm{O}$ record with the foraminiferal biostratigraphy (Kohl, this volume) and the tephrochronology (Ledbetter, this volume). The high sedimentation rates in Pigmy Basin make it possible to examine the paleoenvironmental and sedimentological history of this basin in terms of meltwater influx and sealevel changes during the late Pleistocene. In addition, a preliminary interpretation is made of the $\delta^{13} \mathrm{C}$ and total carbonate records of Site 619.

\section{METHODOLOGY}

Sediment samples ranging in volume from 20 to $40 \mathrm{~cm}^{3}$ were taken at 1- to 50-cm intervals from the HPC sections recovered at Site 619. Separation of the foraminifers from the samples for isotopic and bio-

${ }^{1}$ Bouma, A. H., Coleman, J. M., Meyer, A. W., et al., Init. Repts. DSDP, 96: Washington (U.S. Govt. Printing Office).

2 Addresses: (Williams) Department of Geology, University of South Carolina, Columbia, SC 29208; (Kohl) Chevron U.S.A. Inc., 935 Gravier, New Orleans, LA 70112. stratigraphic analyses was done using standardized micropaleontological procedures (Williams, 1976; Kohl, this volume). Specimens of the shallow-dwelling species, Globigerinoides ruber, were removed from the 250- to $350-\mu \mathrm{m}$ fraction of samples which contained sufficient foraminifers for isotopic analysis. Their isotopic compositions were determined using a VG Micromass $602 \mathrm{D}$ according to standard analytical procedures (Williams, 1984). All isotopic data are reported in the conventional delta $\left(\delta^{18} \mathrm{O}\right.$ and $\left.\delta^{13} \mathrm{C}\right)$ notation as the per mil $(\% 0)$ enrichment or depletion relative to PeeDee belemnite (PDB) (Table 1). Recognition of the oxygen-isotope stages is after the criteria established by Williams (1984) as refined from the work of Emiliani (1966), Shackleton and Opdyke (1973), and Imbrie et al. (1984). Total calcium carbonate determinations were also made on an unprocessed portion of each sample by a modified digestion technique (Hulsemann, 1966) (Table 1).

\section{RESULTS AND DISCUSSION}

\section{Description of the Isotopic and Carbonate records}

The oxygen-isotope record (Fig. 1A) has a total range of approximately $3 \% 0$ and a character that illustrates the effects of glacial meltwater signals superimposed on the global ice volume/glacio-eustatic sea level signal for the late Pleistocene (Williams, 1984). For example, interglacial isotope Stages 1, 3, and the late part of 5 as well as glacial isotope Stages 2 and 4 can be recognized. Placement of the $\delta^{18} \mathrm{O}$ stages, the Ericson $\mathrm{Y} / \mathrm{Z}$ and $\mathrm{X} / \mathrm{Y}$ biostratigraphic boundaries, and the Y8 volcanic ash datum (Ledbetter, this volume) are in agreement with the stratigraphy of other Pleistocene sections from the Gulf of Mexico (Williams, 1984; Thunell, 1984). For example, the Stage $1 / 2$ boundary occurs at a sub-bottom depth of $11 \mathrm{~m}$ within a zone characterized by a transitional planktonic fauna and just below the Ericson $\mathrm{Z} / \mathrm{Y}$ biostratigraphic zone at $5 \mathrm{~m}$ (Kohl, this volume). The $\delta^{18} \mathrm{O}$ values at 2.18 and $2.83 \mathrm{~m}$ sub-bottom depth within the Holocene section are anomalously close to glacial-like isotopic values and must await verification to explain their significance. The isotope Stage $2 / 3$ and $3 / 4$ boundaries are chosen at 54 and $112 \mathrm{~m}$, respectively. The isotope Stage $4 / 5$ boundary at $139.8 \mathrm{~m}$ occurs just within the earliest part of the $\mathrm{Y}$ zone (Y/X boundary at $147 \mathrm{~m}$ ) and above the Y8 ash horizon at $142 \mathrm{~m}$ (Ledbetter, this vol- 
D. F. WILLIAMS, B. KOHL

Table 1. Isotopic and $\mathrm{CaCO}_{3}$ analysis of Globigerinoides ruber from Hole 619 (Pigmy Basin).

\begin{tabular}{|c|c|c|c|c|}
\hline $\begin{array}{l}\text { Core-Section } \\
\text { (interval in cm) }\end{array}$ & $\begin{array}{l}\text { Sub-bottom } \\
\text { depth } \\
\text { (m) }\end{array}$ & $\underset{\left(\%_{00}\right)}{\delta^{18} \mathrm{O}_{\mathrm{PBD}}}$ & $\delta_{\left({ }^{13} \mathrm{C}_{\mathrm{PDB}}\right)}$ & $\begin{array}{c}\mathrm{CaCO}_{3} \\
(\%)\end{array}$ \\
\hline $1-1,22-26$ & 1.24 & -1.38 & 0.95 & 16.3 \\
\hline $1-1,30-35$ & 1.32 & -0.93 & 0.79 & 10.1 \\
\hline $1-1,70-75$ & 1.72 & -1.63 & 0.98 & \\
\hline $1-1,110-115$ & 2.12 & -1.55 & 0.98 & \\
\hline $1-1,115-120$ & 2.18 & -0.01 & 1.17 & \\
\hline $1-2,15-20$ & 2.65 & -0.81 & 0.68 & \\
\hline $1-2,22-26$ & 2.74 & -0.94 & 0.81 & \\
\hline $1-2,30-35$ & 2.82 & -0.81 & 0.95 & 11.2 \\
\hline $1-2,110-115$ & 3.62 & -1.58 & 0.72 & \\
\hline $1-2,122-127$ & 3.74 & -1.78 & 0.22 & \\
\hline $1-3,30-35$ & 4.32 & -1.70 & 0.35 & 12.0 \\
\hline $1-2,70-75$ & 4.72 & -1.69 & 0.28 & \\
\hline $1-3,110-115$ & 5.12 & -1.08 & 0.60 & \\
\hline $1-4,22-26$ & 5.74 & & & 7.7 \\
\hline $1-4,30-35$ & 5.82 & -1.95 & 0.18 & 8.5 \\
\hline $1-5,22-26$ & 7.24 & & & 6.6 \\
\hline $1-5,30-35$ & 7.32 & & & 9.1 \\
\hline $1-6,22-26$ & 8.74 & -1.19 & 1.35 & 5.7 \\
\hline $1-6,30-35$ & 8.82 & & & 6.1 \\
\hline $3-1,25-30$ & 10.77 & & & 5.7 \\
\hline $3-1,30-35$ & 10.85 & & & 5.1 \\
\hline $3-2,25-30$ & 12.27 & -1.10 & 0.73 & 9.2 \\
\hline $3-2,70-75$ & 12.72 & & & 10.5 \\
\hline $3-3,30-35$ & 13.82 & & & 10.1 \\
\hline $3-3,110-115$ & 14.62 & -0.49 & 0.62 & \\
\hline $3-4,30-35$ & 15.32 & & & 10.0 \\
\hline $3-4,110-115$ & 16.12 & -0.31 & 0.24 & \\
\hline $3-5,25-30$ & 16.78 & -0.31 & 0.57 & 11.1 \\
\hline $3-5,30-35$ & 16.83 & -0.99 & 0.65 & 12.6 \\
\hline $3-5,110-115$ & 17.63 & -0.41 & 0.53 & \\
\hline $3-6,25-30$ & 18.28 & & & 9.5 \\
\hline $3-6,30-35$ & 18.33 & & & 8.5 \\
\hline $4-1,25-30$ & 20.48 & & & 8.8 \\
\hline $4-1,30-35$ & 20.53 & & & 10.1 \\
\hline $4-2,25-30$ & 21.98 & & & 9.5 \\
\hline $4-2,30-35$ & 22.03 & & & 10.0 \\
\hline $4-3,30-35$ & 23.53 & & & 9.6 \\
\hline $4-4,30-35$ & 25.03 & & & 9.6 \\
\hline $4-4,70-75$ & 25.43 & -0.56 & 0.54 & \\
\hline $4-4,103-108$ & 25.76 & -0.04 & 0.48 & 10.0 \\
\hline $4-4,110-115$ & 25.83 & -0.97 & 0.52 & \\
\hline $4-5,25-30$ & 26.48 & 0.13 & 0.94 & 10.6 \\
\hline $4-5,30-35$ & 26.53 & -0.23 & 0.75 & 11.7 \\
\hline $4-5,70-75$ & 26.93 & -0.60 & 0.64 & \\
\hline $4-5,110-115$ & 27.33 & -0.53 & 0.48 & \\
\hline $4-6,30-35$ & 28.03 & -0.34 & 0.72 & 10.8 \\
\hline $5-1,30-35$ & 30.23 & & & 10.9 \\
\hline $5-2,30-35$ & 31.73 & & & 12.0 \\
\hline $5-2,70-75$ & 32.13 & -0.48 & 0.41 & \\
\hline $5-3,30-35$ & 33.23 & & & 14.0 \\
\hline $5-4,25-30$ & 34.68 & -0.83 & 0.13 & 10.8 \\
\hline $5-4,30-35$ & 34.73 & & & 10.4 \\
\hline $5-5,30-35$ & 36.23 & -0.38 & 0.51 & 9.6 \\
\hline $6-1,30-35$ & 39.93 & & & 7.4 \\
\hline $6-1,30-35$ & 40.33 & -0.55 & 0.48 & 7.7 \\
\hline $6-2,30-35$ & 41.43 & & & 9.9 \\
\hline $6-2,110-115$ & 42.23 & -0.54 & 0.61 & \\
\hline $6-3,30-35$ & 42.93 & & & 9.3 \\
\hline $6-3,70-75$ & 43.33 & -0.56 & 0.42 & \\
\hline $6-4,30-35$ & 44.43 & -0.82 & 0.53 & 10.8 \\
\hline $6-5,30-35$ & 45.93 & & & 9.4 \\
\hline $6-6,30-35$ & 47.43 & & & 10.2 \\
\hline $7-1,25-30$ & 49.58 & & & 10.3 \\
\hline $7-1,30-35$ & 49.63 & & & 10.4 \\
\hline $7-2,30-35$ & 51.13 & & & 10.8 \\
\hline $7-3,30-35$ & 52.63 & 0.30 & 0.57 & 10.8 \\
\hline $7-3,103-108$ & 53.36 & & & 9.9 \\
\hline $7-4,30-35$ & 54.13 & & & 10.1 \\
\hline $7-4,70-75$ & 54.53 & -0.35 & 0.50 & \\
\hline $7-5,30-35$ & 55.63 & & & 12.6 \\
\hline $7-5,103-108$ & 56.36 & -0.75 & 0.49 & 12.4 \\
\hline $8-1,30-35$ & 59.33 & & & 11.8 \\
\hline $8-1,103-108$ & 60.06 & -1.24 & 0.86 & 11.1 \\
\hline $8-2,30-35$ & 60.83 & & & 11.0 \\
\hline $8-3,25-30$ & 62.28 & & & 12.5 \\
\hline
\end{tabular}

Table 1 (continued).

\begin{tabular}{|c|c|c|c|c|}
\hline $\begin{array}{l}\text { Core-Section } \\
\text { (interval in cm) }\end{array}$ & $\begin{array}{l}\text { Sub-bottom } \\
\text { depth } \\
\text { (m) }\end{array}$ & $\begin{array}{c}\delta^{18} \mathrm{O}_{\mathrm{PBD}} \\
\left.(\%)_{0}\right)\end{array}$ & $\underset{(\% 0)}{\delta^{13} C_{\text {PDB }}}$ & $\underset{(\%)}{\mathrm{CaCO}_{3}}$ \\
\hline $8-3,30-35$ & 62.33 & & & 11.1 \\
\hline $8-4,30-35$ & 63.83 & & & 12.3 \\
\hline $8-4,110-115$ & 64.63 & -0.84 & -0.13 & \\
\hline $9-1,25-30$ & 68.97 & -0.95 & 0.49 & \\
\hline $9-1,30-35$ & 69.02 & & & 12.9 \\
\hline $9-2,30-35$ & 70.52 & -0.54 & 0.09 & 12.9 \\
\hline $9-3,25-30$ & 71.97 & -1.13 & 0.40 & 11.0 \\
\hline $9-3,30-35$ & 72.02 & & & 11.9 \\
\hline $10-2,25-30$ & 74.77 & -0.94 & 1.11 & 9.3 \\
\hline $10-2,103-108$ & 75.55 & -0.95 & 0.38 & 14.9 \\
\hline $10-2,110-115$ & 75.62 & -1.36 & 0.83 & \\
\hline $10-3,25-30$ & 76.27 & -0.61 & 0.96 & 15.4 \\
\hline $10-3,103-108$ & 77.05 & -0.59 & 0.18 & 14.8 \\
\hline $10-4,25-30$ & 77.77 & -1.98 & 1.02 & 15.6 \\
\hline $10-4,30-35$ & 77.82 & -1.95 & 0.87 & \\
\hline $10-4,103-108$ & 78.55 & -0.74 & 0.25 & 14.7 \\
\hline $10-4,110-115$ & 78.62 & -2.03 & 0.56 & \\
\hline $10-1,30-35$ & 78.72 & & & 13.4 \\
\hline $10-2,30-35$ & 80.22 & & & 9.6 \\
\hline $10-3,30-35$ & 81.72 & & & 14.3 \\
\hline $10-4,30-35$ & 83.22 & & & 15.5 \\
\hline $11-1,25-30$ & 88.27 & 0.06 & 0.24 & \\
\hline $11-1,30-33$ & 88.32 & & & 15.7 \\
\hline $11-2,25-30$ & 89.77 & -1.34 & 0.23 & 16.0 \\
\hline $11-2,30-33$ & 89.82 & & & 16.4 \\
\hline $11-3,30-33$ & 91.32 & & & 13.9 \\
\hline $11-4,25-30$ & 92.77 & & & 10.9 \\
\hline $12-1,30-33$ & 97.93 & & & 13.4 \\
\hline $12-1,103-108$ & 98.65 & & & 13.3 \\
\hline $12-2,30-33$ & 99.43 & & & 13.2 \\
\hline $12-2,103-108$ & 100.15 & & & 13.6 \\
\hline $12-3,30-33$ & 100.93 & & & 13.7 \\
\hline $13-1,30-33$ & 107.52 & -1.34 & 0.79 & 13.7 \\
\hline $13-1,110-113$ & 108.32 & -0.81 & 0.88 & \\
\hline $13-2,30-33$ & 109.02 & -1.29 & 0.99 & 11.9 \\
\hline $13-3,25-30$ & 110.47 & -0.41 & 0.60 & \\
\hline $13-3,30-33$ & 110.52 & -1.44 & 0.33 & 12.7 \\
\hline $13-3,103-108$ & 111.25 & -0.81 & 0.62 & 12.4 \\
\hline $13-3,110-113$ & 111.32 & -2.13 & 0.85 & \\
\hline $13-4,25-30$ & 111.97 & -0.75 & 0.47 & 11.4 \\
\hline $13-4,30-33$ & 112.02 & & & 13.4 \\
\hline $13-4,70-73$ & 112.42 & -1.00 & 1.03 & \\
\hline $13-4,73-74$ & 112.43 & -0.05 & 0.74 & \\
\hline $14-1,30-33$ & 117.12 & & & 15.4 \\
\hline $14-2,30-33$ & 118.62 & & & 12.7 \\
\hline $15-1,25-30$ & 126.67 & 0.46 & 0.78 & \\
\hline $15-1,30-33$ & 126.72 & -0.61 & 0.80 & 13.7 \\
\hline $15-1,103-108$ & 127.45 & -0.89 & 0.48 & 11.2 \\
\hline $15-1,110-113$ & 127.52 & -0.13 & 0.73 & \\
\hline $15-2,25-30$ & 128.17 & -0.79 & 0.55 & \\
\hline $15-2,30-33$ & 128.22 & & & 12.8 \\
\hline $15-2,103-108$ & 128.95 & -1.53 & 0.46 & 10.8 \\
\hline $15-3,25-30$ & 129.67 & & & 10.7 \\
\hline $15-3,30-33$ & 129.72 & & & 11.3 \\
\hline $16-1,25-28$ & 136.27 & -0.38 & 0.89 & \\
\hline $16-1,35-40$ & 136.37 & 0.01 & 0.59 & 3.3 \\
\hline $16-1,115-120$ & 137.17 & -0.59 & 1.12 & \\
\hline $16-2,35-40$ & 137.87 & & & 11.0 \\
\hline $16-2,35-40$ & 138.34 & -1.14 & 1.24 & \\
\hline $16-2,103-106$ & 138.55 & -0.91 & 0.80 & 19.3 \\
\hline $16-3,25-28$ & 139.27 & -0.77 & 0.50 & \\
\hline $16-3,35-40$ & 139.37 & & & 9.2 \\
\hline $16-3,131-133$ & 140.32 & & & 10.8 \\
\hline $16-4,29-31$ & 140.80 & -0.95 & 0.43 & 23.1 \\
\hline $16-4,35-40$ & 140.87 & & & 12.0 \\
\hline $16-4,67-72$ & 141.16 & -2.54 & 1.41 & \\
\hline $16-4,72-74$ & 141.23 & -1.72 & 0.59 & 10.0 \\
\hline $16-0,10-12$ & 141.64 & & & 7.5 \\
\hline $17-1,15-20$ & 145.86 & & & 8.4 \\
\hline $17-1,103-108$ & 146.76 & & & 7.6 \\
\hline $17-2,15-20$ & 147.38 & & & 15.5 \\
\hline $6-4,30-35$ & 147.43 & -0.73 & 0.31 & \\
\hline $17-2,20-25$ & 147.52 & -1.18 & 0.48 & \\
\hline $17-2,110-115$ & 148.33 & -1.48 & 0.68 & \\
\hline $17-3,13-16$ & 148.85 & -0.72 & 0.52 & \\
\hline
\end{tabular}


Table 1 (continued).

\begin{tabular}{|c|c|c|c|c|}
\hline $\begin{array}{l}\text { Core-Section } \\
\text { (interval in } \mathrm{cm} \text { ) }\end{array}$ & $\begin{array}{l}\text { Sub-bottom } \\
\text { depth } \\
\text { (m) }\end{array}$ & $\begin{array}{c}\delta^{18} \mathrm{O}_{\mathrm{PBD}} \\
\left(\%_{0}\right)\end{array}$ & $\begin{array}{c}\delta^{13} \mathrm{C}_{\mathrm{PDB}} \\
\left(\%_{0}\right)\end{array}$ & $\begin{array}{c}\mathrm{CaCO}_{3} \\
(\%)\end{array}$ \\
\hline $17-3,15-20$ & 148.87 & & & 10.8 \\
\hline $17-3,45-50$ & 149.17 & -2.13 & 1.05 & \\
\hline $17-3,51-54$ & 149.23 & -0.68 & 0.10 & 17.0 \\
\hline $17-3,122-126$ & 149.94 & -1.24 & 0.79 & \\
\hline $17-4,15-20$ & 150.38 & -1.23 & 0.66 & 8.6 \\
\hline $17-0,8-10$ & 150.64 & -0.78 & 0.47 & 12.0 \\
\hline $18-1,0-3$ & 155.41 & & & 5.1 \\
\hline $18-1,30-33$ & 155.71 & & & 5.1 \\
\hline $18-1,77-80$ & 156.18 & -1.23 & 1.33 & \\
\hline $18-1,121-124$ & 156.63 & -1.10 & 0.38 & \\
\hline $18-2,0-3$ & 156.91 & -1.51 & 0.69 & 11.8 \\
\hline $18-0,6-11$ & 158.25 & & & 4.6 \\
\hline $18-0,12-15$ & 158.31 & & & 5.9 \\
\hline $19-1,10-13$ & 165.23 & & & 4.5 \\
\hline $19-1,84-89$ & 165.96 & & & 3.3 \\
\hline $19-2,10-13$ & 166.73 & & & 3.3 \\
\hline $19-2,84-89$ & 167.46 & & & 4.1 \\
\hline $19-3,10-13$ & 168.23 & & & 3.4 \\
\hline $19-3,30-35$ & 168.43 & & & 5.1 \\
\hline $20-1,15-18$ & 174.86 & & & 4.2 \\
\hline $20-1,38-42$ & 175.10 & & & 4.1 \\
\hline $20-2,32-35$ & 176.54 & & & 4.2 \\
\hline $20-3,2-5$ & 177.73 & & & 3.8 \\
\hline $22-1,2-7$ & 187.34 & & & 6.8 \\
\hline $22-1,30-35$ & 187.62 & -1.49 & 0.73 & \\
\hline $22-1,40-45$ & 187.72 & 0.85 & 1.45 & \\
\hline $22-1,100-105$ & 188.32 & -1.80 & 0.43 & \\
\hline $22-1,118-121$ & 188.49 & -0.07 & 1.02 & \\
\hline $22-2,2-7$ & 188.84 & & & 7.2 \\
\hline $22-2,32-37$ & 189.14 & -1.09 & 1.01 & \\
\hline $22-2,62-67$ & 189.44 & -0.87 & 0.45 & \\
\hline $22-0,7-13$ & 189.58 & -1.84 & -0.08 & \\
\hline $22-0,18-23$ & 189.69 & & & 6.6 \\
\hline $25-1,20-23$ & 207.92 & & & 5.0 \\
\hline
\end{tabular}

ume). These isotope, faunal, and ash placements are consistent with the latest stratigraphy of the late Pleistocene Gulf of Mexico as shown in numerous piston cores (Rabek et al., 1985).

In addition to a stratigraphic signal, the $\delta^{18} \mathrm{O}$ record at Site 619 contains evidence of repeated influxes of isotopically negative runoff into the Gulf of Mexico (Fig. 1A). It is not presently possible to determine whether these negative events correspond with fluvial episodes or periods of freshwater from melting of the southern portion of the Laurentide ice sheet. Sampling gaps between 9-12 and 18-25 m sub-bottom depth intervals (Site 619 chapter, this volume) preclude resolution of the well-documented isotopic anomalies associated with the last deglaciation (Kennett and Shackleton, 1975; Emiliani et al., 1975; Leventer et al., 1982, 1983), but negative events in Stages 2, 3, 4 and late Stage 5 show evidence for surface salinity changes in the Gulf of Mexico during times other than glacial terminations (Fig. 1A).

The carbon-isotope record for Site 619 (Fig. 1B) has a total range of approximately $1.5 \%$ consistent with the surface water $\delta^{13} \mathrm{C}$ record for the Gulf of Mexico (Williams, 1985). The lightest $\delta^{13} \mathrm{C}$ values correspond to the early part of Stage 2 and the latest part of Stage 3. Several large positive and negative $\delta^{13} \mathrm{C}$ events $(>0.7 \%$ ) occur near the top of Stage 1, between 75 and $80 \mathrm{~m}$ in Stage 3 , in early Stage 4, and late Stage 5 . No long term trends are readily discernible.
As expected, the total carbonate contents (weight \%) of Site 619 sediments are low ( 3 to $23 \%$, with an average centered around 10\%; Fig. 1C). Rapid changes on the order of 6 to $10 \%$ are common throughout the record but no clear relationship exists between relative carbonate minima or maxima and the isotope stages (Fig. 1A). The broadest $\mathrm{CaCO}_{3}$ maxima with contents consistently greater than $12 \%$ occur during Stage 3 . The lowest Ca$\mathrm{CO}_{3}$ values ( 3 to $6 \%$ ) occur near the Stage $1 / 2$ boundary, in early Stage 4 and in late Stage 5 (Substages 5b$5 c$ ?). There appears to be a second-order correlation, however, between high spikes in the $\mathrm{CaCO}_{3}$ record and negative $\delta^{18} \mathrm{O}$ values in the oxygen-isotope record, perhaps related to meltwater or runoff events. For example, the negative $\delta^{18} \mathrm{O}$ spikes at $16.8,25.8$, and $44.4 \mathrm{~m}$ in Stage 2 have coincident $\mathrm{CaCO}_{3}$ spikes, as do the $\delta^{18} \mathrm{O}$ events in Stages 3, 4, and 5 at 77.8, 78.6, 110.5, 111.3, 141.1 , and $149.1 \mathrm{~m}$ sub-bottom depth. The implications for these correlations will be discussed in a later section.

\section{Chronostratigraphy and Paleoenvironmental Interpretation}

Placement of the oxygen-isotope stages as shown in Figure 1A along with the planktonic foraminiferal biostratigraphy (Kohl, this volume) and tephrochronology (Ledbetter, this volume) allow us to estimate sedimentation rates at Site 619 and establish the chronostratigraphy shown in Figures 2 and 3. The ages for the isotopestage boundaries are taken to be $13,000 \mathrm{yr}$. ago for Stage $1 / 2,32,000$ yr. ago for Stage 2/3, 64,000 yr. ago for Stage 3/4, and 75,000 yr. ago for Stage 4/5 (Imbrie et al., 1984). An age of 105,000 yr. ago is assumed for the bottom of the section based on the absence of a well-defined $\mathrm{W}$ zone and the lack of definition of the substages of Stage 5 (Shackleton and Opdyke, 1973; Williams, 1984). The fact that the sedimentary section at Site 619 was alternately washed and hydraulic piston cored below $73 \mathrm{~m}$ sub-bottom depth precludes further refinement of the chronostratrigraphic record at this time. However, several interesting observations can still be made.

First, the sedimentation rates at Site 619 are very high, exceeding $2 \mathrm{~m}$ per thousand years in Stages 2 and 4 (Fig. $2)$. The rate in Stage $3(1.81 \mathrm{~m} / 1000 \mathrm{yr}$. $)$ is nearly equal to the rates in Stages 2 and 4. The positions of both the $\mathrm{Z}$ zone and isotope Stage 1/2 boundary indicate that either the top most part of the Holocene is missing at Site 619 (most likely because of washing upon entry of the HPC) or Pigmy Basin experienced a sharp decrease in sediment input during the Holocene $(0.5$ or $0.85 \mathrm{~m} / 1,000$ $\mathrm{yr}$. depending on whether the base of the $\mathrm{Z}$ zone or the Stage $1 / 2$ boundary is used). The most noticeable rate change, however, occurs at the Stage $4 / 5$ boundary, below which the average sedimentation rate is less than $0.4 \mathrm{~m} / 1000 \mathrm{yr}$., still an order of magnitude greater than in most deep-sea cores but much less than in the rest of Site 619 (Fig. 2).

Despite these problems, the high sedimentation rates at Site 619 permit isotopic and carbonate records of excellent resolution in those sections recovered in the coring process (Fig. 3). The $\delta^{18} \mathrm{O}$ record in particular shows 


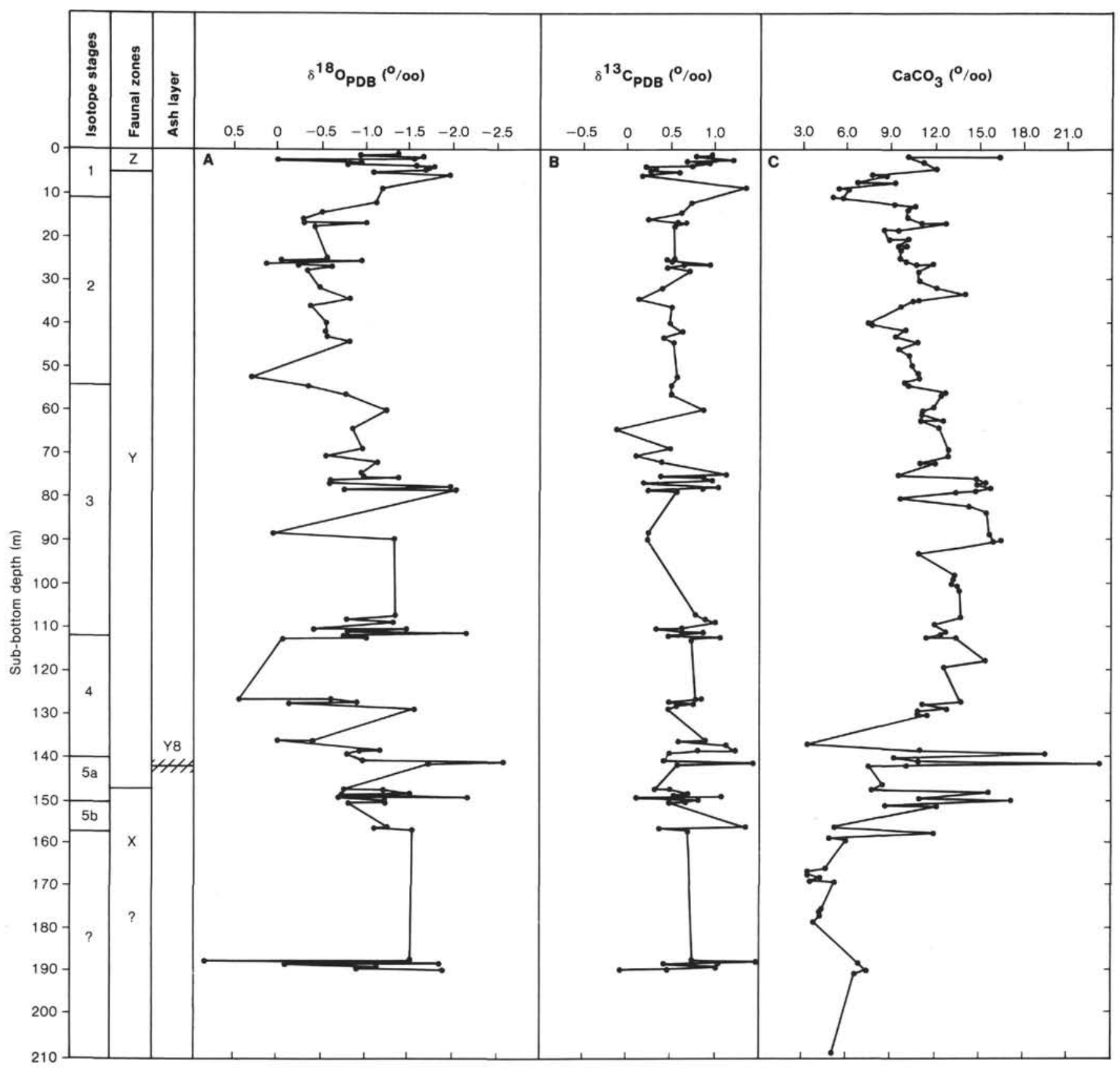

Figure $1 . \delta^{18} \mathrm{O}(\mathrm{A}), \delta^{13} \mathrm{C}(\mathrm{B})$, and total $\mathrm{CaCO}_{3}(\mathrm{C})$ records versus sub-bottom depth $(\mathrm{m})$ at Site 619 . The $\delta^{18} \mathrm{O}$ and $\delta^{13} \mathrm{C}$ values are determined from $\mathrm{Glo}$ bigerinoides ruber relative to PDB (Table 1).

that surface waters off the Louisiana slope were repeatedly affected by freshwater runoff episodes at 13,600 , $15,600,19,600$ and 27,800 yr. ago during Stage 2 , at $35,000,42,800$ to 44,300 , and 60,700 yr. ago during the interstadial conditions of Stage 3 , at 69,700 yr. ago during Stage 4 and at 79,400, 88,000, and 103,000 yr. ago during Stage 5 (5a-5c?) (Fig. 3A). The magnitude of the two meltwater anomalies at 60,700 and 42,800 to 44,300 yr. ago in Stage 3 are particularly large, depleted in ${ }^{18} \mathrm{O}$ by more than $1 \%$ compared to "normal" isotope values expected for Stage 3 in this region of the Gulf of Mexico (Williams, 1984). In between these two meltwater events, a section of approximately $20 \mathrm{~m}$ occurs which consists of a fine grained, nearly unfossiliferous mud with very few foraminifers.

A second observation involves the relationship between carbonate and clastic sedimentation in Pigmy Basin with respect to its proximity to the clastic inputs from the northern shelf and upper slope. Instead of clastic dilution controlling the $\mathrm{CaCO}_{3}$ content of Site 619 sediments, fluctuations in the $\mathrm{CaCO}_{3}$ record appear to be related to the freshwater runoff episodes as evidenced by the correspondence of numerous $\mathrm{CaCO}_{3}$ maxima with negative $\delta^{18} \mathrm{O}$ events (Figs. 1, 3). For example, the fine grained, nearly unfossiliferous interval in Stage 3 that is bracketed by two large $\delta^{18} \mathrm{O}$ events has a relatively high $\mathrm{CaCO}_{3}$ 


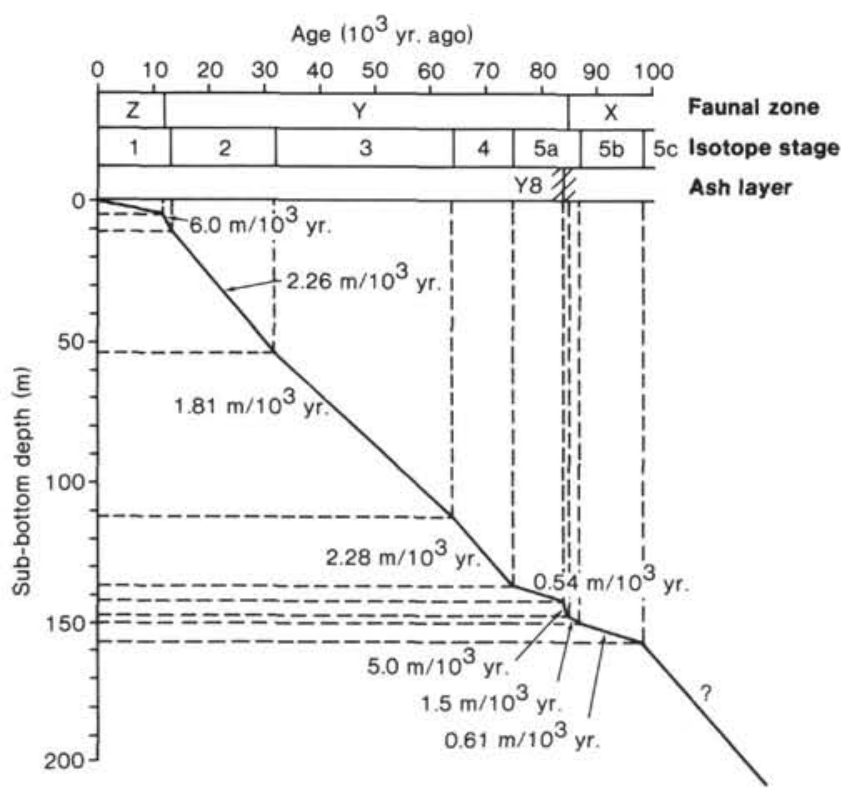

Figure 2. Sedimentation rate diagram for Site 619 using the depth occurrences of the biostratigraphic zones, isotope stages, and ash layer (Ledbetter, this volume).

content of approximately $12 \%$ (Fig. 1). This coincidence is exactly the opposite of what one would expect, that is, enhanced siliciclastic input with meltwater runoff from the North American continent, not carbonate. Sediments from the runoff intervals that have been examined appear to contain significant quantities of reworked Cretaceous nannofossils (R. Constans, pers. comm., 1984). On the contrary, however, the lowest $\mathrm{CaCO}_{3}$ contents occur at sub-bottom depths greater than $157 \mathrm{~m}$ when (a) the Pigmy Basin was open to bottom-hugging density flows (Kohl, this volume), (b) the stratigraphic framework of Site 619 becomes confused due to a lack of datum horizons, and (c) faunal evidence exists for slumping and/or reworking of Cretaceous foraminifers and radiolarians (Kohl, this volume).

\section{CONCLUSIONS}

The most important results of this study are (1) the evidence for the influx of significant quantities of freshwater into the Gulf of Mexico during times other than major deglaciations. Future faunal and isotopic work on Site 619 sediments may provide information that can be translated into an understanding of the dynamics of the midlatitude, midcontinental portion of the Laurentide ice sheet during the last $110,000 \mathrm{yr}$., (2) the development of a chronostratigraphy for the upper $200 \mathrm{~m}$ of the sediment column in Pigmy Basin within which to model the relationship between lithotype, glacio-eustatic sea level changes, and seismic character of intraslope basin sediments; and (3) the possibility that fine-grained, reworked carbonate may be deposited on the Gulf Coast continental margin during periods of enhanced freshwater runoff.

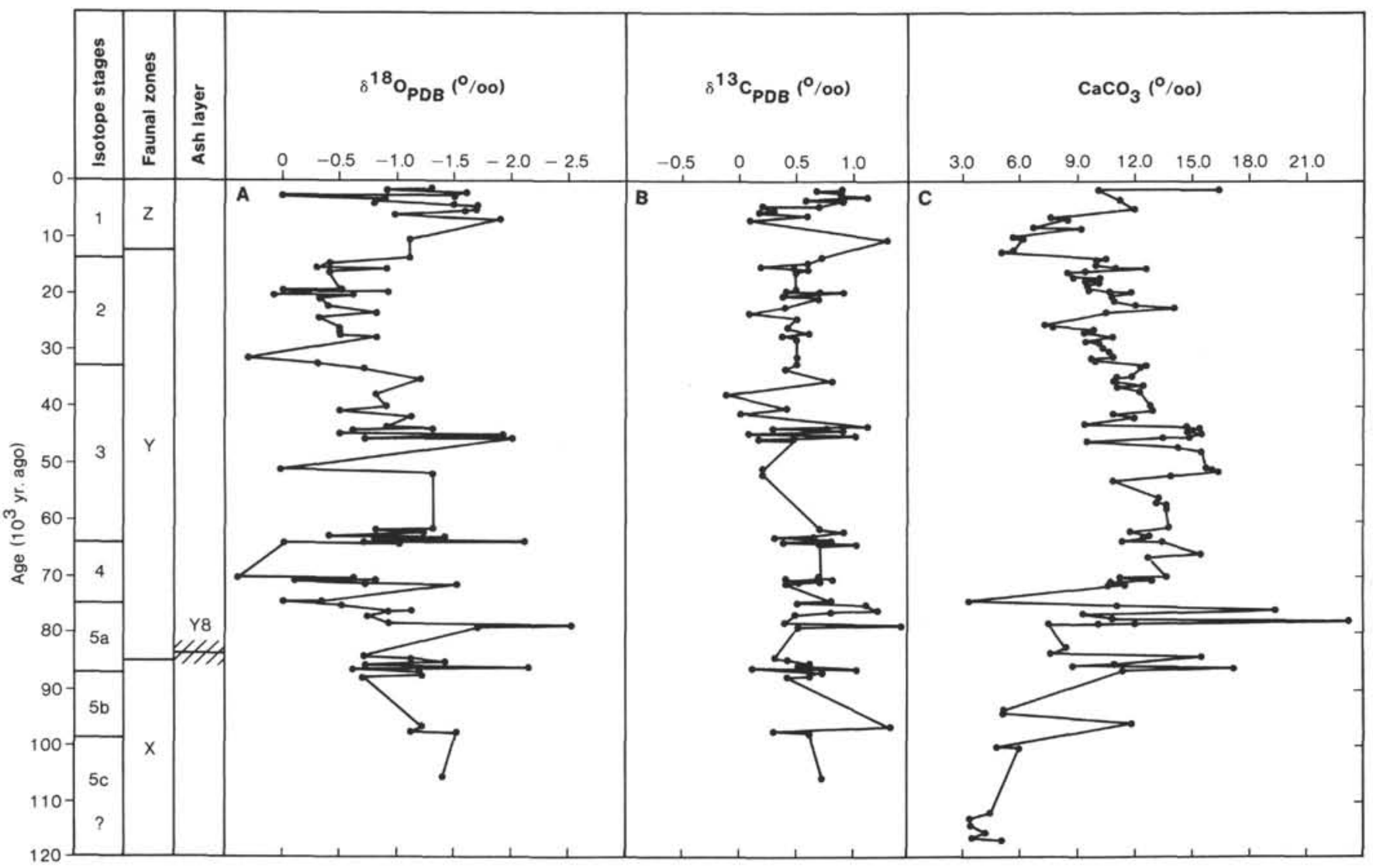

Figure 3. $\delta^{18} \mathrm{O}(\mathrm{A}), \delta^{13} \mathrm{C}(\mathrm{B})$, and total $\mathrm{CaCO}_{3}(\mathrm{C})$ records versus time $\left(10^{3} \mathrm{yr}\right.$. ago) at Site 619 using the age relationships shown in Figure 2. 


\section{ACKNOWLEDGMENTS}

The senior author thanks Arnold H. Bouma, James M. Coleman, Audrey W. Meyer and two anonymous reviewers for their criticisms of an early draft; Michael Ledbetter for sharing his tephrochronology results; Mary Evans, David Mucciarone, Steve Hardin, and Jeff Corbin of the Stable Isotope Laboratory for their assistance with the isotopic and carbonate analyses; and Donna Black and Joyce Goodwin for word processing the manuscript. This work was partially supported by NSF Grant OCE82-08911 and Gulf Oil Corporation.

\section{REFERENCES}

Bouma, A. H., 1983. Intraslope basins in northwest Gulf of Mexico: A key to ancient submarine canyons and fans. In Watkins, J. S., and Drake, C. L. (Eds.), Studies in Continental Margin Geology. Am. Assoc. Pet. Geol. Mem., 34:567-581.

Emiliani, C., 1966. Paleotemperature analysis of Caribbean cores P6304-8 and P6304-9 and a generalized temperature curve for the last 425,000 years. J. Geol., 74:109-126.

Emiliani, C., Gartner, S., Lidz, B., Eldridge, K., Elvey, D. K., et al., 1975. Paleoclimatological analysis of Late Quaternary cores from the northeastern Gulf of Mexico. Science, 189:1083-1088.

Gealy, B. L., 1955. Topography of the continental slope in northwest Gulf of Mexico. Geol. Soc. Am. Bull., 66:203-227.

Hulsemann, J., 1966. On the routine analysis of carbonates in unconsolidated sediments. J. Sediment. Petrol., 36:622-625.

Imbrie, J. Hays, J. D., Martinson, D. G., McIntyre, A., Mix, A. C., et al., 1984. The orbital theory of Pleistocene climate: support for a revised chronology of the marine $\delta^{18} \mathrm{O}$ record. In Berger, A., Imbrie, J., Hays, J., Kukla, G., and Saltzman, B. (Eds.), Milankovitch and Climate: Boston (Riedel), pp. 269-306.

Kennett, J. P., and Shackleton, N. J., 1975. Laurentide ice sheet meltwater recorded in Gulf of Mexico deep-sea cores. Science, 188: $147-150$.

Leventer, A., Williams, D. F., and Kennett, J. P., 1982. Dynamics of Laurentide ice sheet during the last glaciation: evidence from the Gulf of Mexico. Earth Planet. Sci. Lett., 59:11-17.
1983. Relationships between anoxia, glacial meltwater and microfossil preservation in the Orca Basin, Gulf of Mexico. Mar. Geol., 53:23-40.

Martin, R. G., and Bouma, A. H., 1978. Physiography of Gulf of Mexico. In Bouma, A. H., Moore, G. T., and Coleman, J. M. (Eds.), Framework, Facies, and Oil Trapping Characteristics of the Upper Continental Margin. Am. Assoc. Pet. Geol., 7:3-19.

Murray, G. E., 1961. Geology of the Atlantic and Gulf Coastal Province of North America: New York (Harper).

Powell, L. C., and Woodbury, H. O., 1971. Possible future petroleum potential of Pleistocene, western Gulf Basin. In Cram, I. H. (Ed.), Future Petroleum Provinces of the United States-Their Geology and Potential. Am. Assoc. Pet. Geol. Mem., 15(2):813-823.

Rabek, K. V. E., Ledbetter, M. T., and Williams, D. F., 1985. Late Pleistocene tephrochronology. Quat. Res., 23:403-416.

Shackleton, N. J., and Opdyke, N. D., 1973. Oxygen isotope and paleomagnetic stratigraphy of equatorial Pacific core V28-238: Oxygen isotope temperatures and ice volumes on a $10^{5}$ year and $10^{6}$ year scale. Quat. Res., 3:39-55.

Thunell, R. C., 1984. Pleistocene planktonic foraminiferal biostratigraphy and paleoclimatology of the Gulf of Mexico. In Healy-Williams, N. (Ed.), Principles of Pleistocene Stratigraphy Applied to the Gulf of Mexico: Boston (IHRDC Press), pp. 25-64.

Williams, D. F., 1976. Late Quaternary fluctuations of the polar front and subtropical convergence in the southeast Indian Ocean. Mar. Micropaleontol., 1:363-375.

1984. Correlation of Pleistocene marine sediments of the Gulf of Mexico and other basins using oxygen isotope stratigraphy, In Healy-Williams, N. (Ed.), Principles of Pleistocene Stratigraphy Applied to the Gulf of Mexico: Boston (IHRDC Press), pp. 67-118.

1985. Carbon isotope variations in surface waters of the Gulf of Mexico on time scales of 10,000,30,000,150,000 and 2 million years. In Sundquist, E. T., and Broecker, W. S. (Eds.), The Carbon Cycle and Atmospheric $\mathrm{CO}_{2}:$ Natural Variations Achean to Present: Washington, D.C. (Am. Geophys. Union), pp. 329-342.

Date of Initial Receipt: 10 December 1984 Date of Acceptance: 2 August 1985 